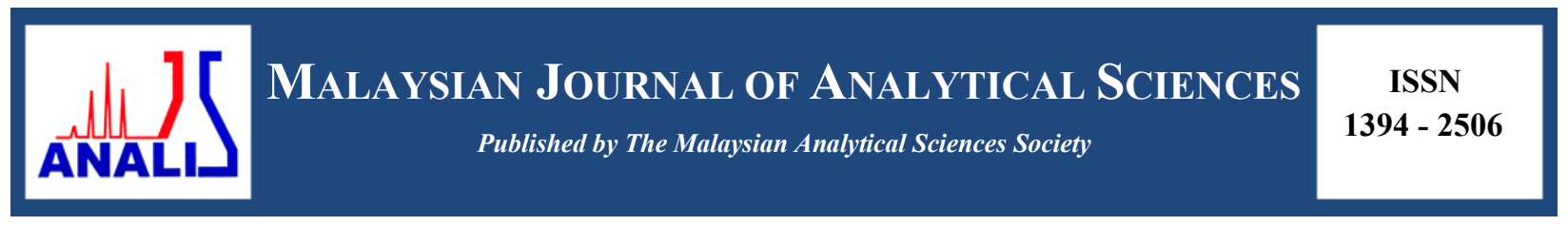

\title{
PALM OIL-BASED PRECURSORS FOR DEVELOPMENT OF POLYMERIC DELIVERY SYSTEM
}

\author{
(Pelopor Berasaskan Minyak Sawit untuk Pembangunan Sistem Penyampai Polimer) \\ Rida Tajau ${ }^{1,2}$, Rosiah Rohani ${ }^{1 *}$, Wan Nor Roslam Wan Isahak ${ }^{1}$, Mek Zah Salleh ${ }^{2}$ \\ ${ }^{I}$ Department of Chemical and Process Engineering, Faculty of Engineering and Built Environment, \\ Universiti Kebangsaan Malaysia, 43600 UKM Bangi, Selangor, Malaysia \\ ${ }^{2}$ Radiation Processing Technology Division, \\ Malaysia Nuclear Agency, 43000 Kajang, Selangor, Malaysia \\ *Corresponding author: rosiah@ukm.edu.my
}

Received: 21 October 2015; Accepted: 14 June 2016

\begin{abstract}
The use of precursors from natural based polymers offer a more biocompatible and biodegradable properties in producing polymer drug vehicle compared to drug vehicles made from synthetic polymer precursors, which normally found in high molecular weight (MW). High MW polymer will lead to immunologic inflammatory responses due to their lower biodegradability and higher cytotoxicity compared to low MW that could give smaller particle size, higher solubility, higher release efficiency, non-immunogenic, better biodegradability and lower cytotoxicity. Therefore, this study is aimed to produce valuable precursors, particularly to produce epoxidized palm olein (EPOo) and diol, to be used in the development of a new polymeric drug vehicle with low MW. An EPOo was synthesized via in-situ epoxidizing of palm olein (POo) with peracid and sulfuric acid $\left(\mathrm{H}_{2} \mathrm{SO}_{4}\right)$ catalyst. Meanwhile the diol was synthesized using hydroxylation of palm oil-based oleic acid via esterification of oleic acid (OA) with glycerol and 4-dodecylbenzyl sulfonic acid catalyst (DBSA). It was found that both palm oil-based precursors have been successfully synthesized from natural resources of palm oil. Physico-chemical properties of the synthesized precursors showed that the EPOo and the diol possess average molecular weight (MW) between $900-1500 \mathrm{~g} / \mathrm{mol}$ and hydroxyl functionality between 2 and 3, based on the presence of hydroxyl $(\mathrm{O}-\mathrm{H})$ group functionality, showed in the Infra-red (IR) spectra in the range of 3200-3600 $\mathrm{cm}^{-1}$. These low MW palm oil based-precursors have potential uses for the design and development of new properties of polymeric drug vehicle such as acrylated palm olein (APOo) and polyol polyester, which will produce particle size in the range of $100-200 \mathrm{~nm}$ or smaller with high efficiency drug loading and controlled release profiles.
\end{abstract}

Keywords: drug delivery system, palm oil, polymeric nanoparticle

\section{Abstrak}

Penggunaan pelopor dari polimer semulajadi bagi menghasilkan penyampai ubat polimer mempunyai kelebihan tertentu iaitu ianya bersifat bioserasi dan biodegradasi berbanding sistem penyampai ubat yang dibuat daripada pelopor polimer sintetik, kebiasaannya mempunyai berat molekul (MW) yang tinggi. Polimer dengan MW yang tinggi boleh menyebabkan gerak balas keradangan keimunan akibat kurang keterbiodegradasikan dan kesitotoksikan yang tinggi dibandingkan MW yang rendah yang boleh menghasilkan partikel bersaiz lebih kecil, keterlarutan dan kecekapan perlepasan yang tinggi, tidak imunogen, terbiodegradasi dengan lebih baik dan sitotoksiti yang rendah. Oleh itu, kajian ini bertujuan menghasilkan pelopor yang bersifat istimewa, terutamanya minyak sawit olein terepoksida (EPOo) dan diol yang digunakan dalam membangunkan sistem penyampaian ubat dengan MW yang rendah. EPOo telah disintesis menggunakan pengepoksidaan in-situ minyak sawit olein (POo) dengan perasid dan pemangkin asid sulfurik $\left(\mathrm{H}_{2} \mathrm{SO}_{4}\right)$. Sementara itu, diol disintesis menggunakan penghidroksilan minyak sawit oleik menggunakan pengesteran asid oleik (OA) dengan gliserol dan pemangkin asid sulfonik 4-dodesilbenzil (DBSA). Hasil penemuan mendapati kedua-dua pelopor yang berasaskan minyak sawit ini telah berjaya disintesis daripada sumber semulajadi minyak sawit. Sifat fisiko-kimia pelopor yang telah disintesis menunjukkan EPOo dan diol mempunyai berat 
molekul (MW) antara 900-1500 g/mol dan bilangan hidroksil antara 2 dan 3, berdasarkan kehadiran kumpulan berfungsi hidroksil (O-H), yang ditunjukkan dalam spektra Infra-merah (IR) dalam julat 3200-3600 $\mathrm{cm}^{-1}$. Pelopor berasaskan minyak sawit yang mempunyai berat molekul yang rendah berpotensi untuk direkabentuk bagi membangunkan sistem penyampai ubat polimer yang bersifat baru seperti minyak sawit olein terakrilat (APOo) dan poliol poliester, yang menghasilkan partikel bersaiz 100-200 $\mathrm{nm}$ atau lebih kecil dengan kecekapan pemuatan ubat dan profil perlepasan terkawal yang tinggi.

Kata kunci: sistem penyampai ubat, minyak sawit, nanopartikel polimer

\section{Introduction}

Polymers are amongst the most extensively explored and widely use materials as drug vehicles for localized and sustained delivery of drug (medication) to a patient $[1,2]$. There are different types of drug vehicles such as macromolecular carriers (macromolecular prodrugs, protein-macromolecule conjugates and gene medicines complexed with macromolecular carriers), particulate carriers (micro/nanoparticles, liposomes, dendrimers, lipoproteins, nanotubes, micro/nanospheres and micro/nanoemulsions) and cellular carriers (leucocytes, platelets, erythrocytes, nanoerythrocytes, hepatocytes, and fibroblast) [3-5].

Natural polymers are currently gaining a lot of research interest due to their advantages such as utilizing environmental friendly materials and involving low energy process which is way better than the synthetic polymers produced via chemical synthesis. The trend of using palm oil based materials for the development of polymeric drug vehicles is growing due to the natural polymer's biocompatibility compared to the petrochemical-based polymers [6-11]. In addition, the synthetic polymers commonly use chemicals that emits greenhouse gases (GHGs), utilizes high energy during the products preparation and processing and most importantly generates toxic by-products [12]. Thus, the use of renewable feed stock resources such as from palm oil products is receiving numerous interest compared to petrochemical-based products.

In this study, new precursors namely epoxidized palm olein (EPOo) and diol were developed from the palm oil product of palm olein (POo) and oleic acid (OA) for the EPOo and diol, respectively. The chemical reaction of epoxidation and esterification processes were applied in developing a non-toxic and cleaner reaction of the palm oil based-precursors. Epoxidation process is performed using in-situ generated peroxyacetic acid due to several advantages, such as minimum amounts of reactants are needed to prepare the epoxidising reagent and safer preparation and handling, compare using the preformed peroxyacid that had handling problems since the concentrated peroxyacid is unstable and explosive [13]. Besides, the peroxyacetic was selected due to its easy availability, low production cost and stability at high temperatures, compare to the peroxybenzoic acid, peroxyformic acid, peroxyfluoroacetic acid, $m$-chloroperoxybenzoic acid and $m$-nitroperoxybenzoic acid [13-14].

Esterification process is performed with an oleic acid and a 4-dodecylbenzyl sulfonic acid (DBSA) for the diol production, in the absence of solvent. The DBSA was selected because is more efficient catalyst in water where it can act as emulsifier and catalyst compared to other catalysts such as hydrochloric acid, sulphuric acid, phosphoric acid $\left(\mathrm{H}_{3} \mathrm{PO}_{4}\right.$ and $p$-toluenesulfonic acid [15-17]. Besides, the esterification process with the DBSA catalyst is considerable as green process, cheap and high product yields [17].

In this work, the study included synthesizing and characterizing of the synthesized precursors. The EPOo and diol produced from the palm oil product are expected to exhibit promising physicochemical properties and have great potential for application in development of new polymeric drug vehicles.

\section{Materials and Methods}

In both preparations of the EPOo and diol, the experimental set-up used in this work was reported and referred in our previous work $[18,19]$. The set-up consists of reaction flask, mechanical stirrer, thermometer, reflux condenser and oil batch.

\section{Preparation of epoxidized palm olein based precursors}

A food grade palm olein (POo) (FFM Marketing Sdn. Bhd) was used as a feedstock to produce the EPOo while other chemicals in this preparation were purchased from Systerm Chem Ar. Initially the POo was vacuum distilled 
prior to use. Then the POo $(1.62 \mathrm{~mol})$ underwent in-situ epoxidizing in the per-acid solution to form the EPOo at the temperature between $60-65^{\circ} \mathrm{C}$ for 2.5 hours $[14,20]$. The per-acid solution consisted of a glacial acetic acid (4 $\mathrm{mol})$, a hydrogen peroxide $(8.24 \mathrm{~mol})$ and a sulphuric acid $(1 \%)$. The chemicals were purchased from Systerm Chem Ar., Merck and HmBG Chemical, respectively. After the epoxidation reaction was completed, the EPOo was immediately transferred from the reaction flask to $2 \mathrm{~L}$ glass beaker. Next, the EPOo was washed with distilled water and vacuum distilled. The summary of the overall EPOo synthesis process is presented in Figure 1 below.

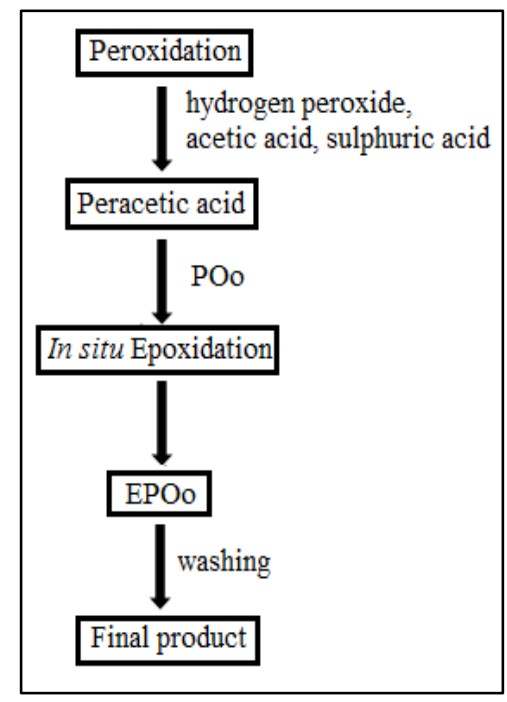

Figure 1. The synthesis routes of the EPOo

\section{Preparation of diol as palm oil based precursors}

On another occasion, oleic acid (OA) (R\&M Chemicals) was vacuum distilled for 3 hours before vacuum recrystallized in acetonitrile. After recrystallization, the OA (1.2 mol) was esterified with glycerol (2.4 mol) and 4dodecylbenzyl sulfonic acid (DBSA) $(0.15 \mathrm{~mol})$ to produce diol at the temperature below $120{ }^{\circ} \mathrm{C}$ for three hours [15]. The chemicals were purchased from R\&M, Systerm Chem Ar. and Fluka, respectively. Next, the synthesized diol was immersed in a mixture solution consist of ethanol (5\%) and natrium chloride (5\%) for 24 hours before vacuum distilled and collected for characterization.

The yield of the reaction for the EPOo and the diol was calculated using Equation (1).

$$
\% \text { Reaction yield }=\left[\frac{\text { Final yield }(\mathrm{g})}{\text { reactant }(\mathrm{g})}\right] \times 100
$$

Characterization of the precursor's physicochemical properties: Oxirane oxygen content (OOC) The OOC test was performed following the standard method of AOCS method Cd 9-57, 1963 [21].

$$
\% \text { OOC }=\frac{(1.6 \times \mathrm{N} \times \mathrm{v})}{\mathrm{w}}
$$

where $\mathrm{N}$ is normality of hydrogen bromide $(\mathrm{HBr})$, while $\mathrm{v}$ is volume of $\mathrm{HBr}$ in $\mathrm{mL}$ and $\mathrm{w}$ is weight of resin in gram.

\section{Acid value}

The acid value (AV) was calculated according to the test method is technically equivalent to ASTM D974 [22]: 


$$
\mathrm{AV}=\frac{(5.61 \times \mathrm{v})}{\mathrm{w}}
$$

where 5.61 is a concentration conversion coefficient (a number of $\mathrm{mg} \mathrm{KOH}$ corresponding to $1 \mathrm{~mL}$ of $0.1 \mathrm{~N} \mathrm{KOH}$ ), $\mathrm{v}$ is volume of $0.1 \mathrm{~N} \mathrm{KOH}$ and $w$ is weight of resin in gram.

\section{Saponification value}

The saponification value (SV) was calculated according to the test method ASTM D 1962-67 [23].

$$
\mathrm{SV}=\frac{[56.1(\mathrm{~B}-\mathrm{S}) \times \mathrm{N}]}{\mathrm{w}}
$$

where $\mathrm{B}$ is volume of $0.5 \mathrm{~N} \mathrm{HCl}$ required by Blank, $\mathrm{S}$ is volume of $0.5 \mathrm{~N} \mathrm{HCl}$ required by Sample, $\mathrm{N}$ is concentration value of $\mathrm{HCl}=0.5 \mathrm{~N}$ and $\mathrm{w}$ is weight of resin in gram.

\section{Iodine value}

The iodine value (IV) was calculated according to the Hanus method as described in the AOCS (Cd 1-25) [24].

$$
\mathrm{IV}=\frac{[(\mathrm{B}-\mathrm{S}) \times \mathrm{N} \times 0.127 \times 100]}{\mathrm{w}}
$$

where $\mathrm{B}$ is volume of $0.1 \mathrm{~N}$ sodium thiosulfate required by Blank, $\mathrm{S}$ is volume of $0.1 \mathrm{~N}$ sodium thiosulfate required by Sample, $\mathrm{N}$ is concentration value of sodium thiosulfate $=0.1 \mathrm{~N}$ and $\mathrm{w}$ is weight of resin in gram.

\section{Ester value}

Ester Value (EV) is defined as the $\mathrm{mg}$ of $\mathrm{KOH}$ required to react with ester content (glycerin or glycerol) after saponification one gram of fat. EV was determined by the equation described in literatures [25-27], where the EV is defined as the difference between the saponification value and acid value:

$$
\mathrm{EV}=\mathrm{SV}-\mathrm{AV}
$$

where $\mathrm{SV}$ is saponification value and $\mathrm{AV}$ is acid value of sample.

\section{Percentage of ester}

Percentage of ester was calculated from ester value and molecular weight by the Equation (7) described by Lubrizol [27]:

$$
\% \text { Ester }=\frac{[(\mathrm{EV})(\mathrm{MW} \text { ester })]}{10 \times 56.1}
$$

where EV is ester value of sample and the value calculated following Equation (6) and MW is molecular weight of ester $=126.11 \mathrm{~g} / \mathrm{mol}$.

\section{Hydroxyl value}

The OHV was calculated according to the test method ASTM D4274-99 Method C [28].

$$
\mathrm{OHV}=\frac{(\mathrm{B}-\mathrm{S}) \times 28.05}{\mathrm{~W}}+\mathrm{AV}
$$

where $\mathrm{B}$ is volume of $0.5 \mathrm{~N}$ ethanolic potassium hydroxide required by Blank, $\mathrm{S}$ is volume of $0.5 \mathrm{~N}$ ethanolic potassium hydroxide required by sample, $\mathrm{w}$ is weight of resin in gram and AV is acid value of sample. 
Hydroxyl number functionality

The hydroxyl number functionality (OHf) was determined by the equation described by Ionescu [29] and used known hydroxyl value and molecular weight of sample:

$$
\mathrm{OHf}=\frac{\mathrm{OHV} \times \mathrm{MW}}{56100}
$$

where $\mathrm{OHV}$ is hydroxyl value of sample and MW is average molecular weight of sample.

\section{Dynamic viscosity}

The dynamic viscosities of the products in liquid form were measured using Brookfield viscometer (Model RV: DVII + Pro) at $25{ }^{\circ} \mathrm{C}$ [30]. The spindle plate with grade 40 and CPE-44PY cup were selected for measuring viscosity.

\section{Average molecular weight}

The average molecular weight of sample was determined by the equation described by $\mathrm{Xu}$ et al. [31] by using known saponification value (SV) and acid value (AV) of sample.

$$
\text { Average Molecular Weight }=\frac{168300}{\text { SV-AV }}
$$

where SV is saponification value and the value was obtained using method (iii) and calculated following Equation (4) and AV is acid value and the value was obtained using method (ii) and calculated using Equation (3).

\section{Fourier transform infrared spectroscopy}

The infrared (IR) spectroscopy of the samples was performed using diamond attenuated total reflectance (DATR) technique. The infrared spectrums of the samples were recorded in the range of $4000 \mathrm{~cm}^{-1}$ to $650 \mathrm{~cm}^{-1}$ by spectrum 400, FT-IR/FTNIR spectrometer (Perkin Elmer, UK).

\section{Thermogravimetric analysis}

Thermogravimetric analysis (TGA) was performed using the TGA-SDTA 851e Mettler Toledo instrument (USA). Samples were analyzed in temperature range from $27{ }^{\circ} \mathrm{C}$ to $800{ }^{\circ} \mathrm{C}$, heating rate of $10{ }^{\circ} \mathrm{C} / \mathrm{min}$.

\section{Differential scanning calorimetry}

Differential scanning calorimetry (DSC) was carried out using the DSC 822, Mettler Toledo instrument (USA). Samples were scanned at $5{ }^{\circ} \mathrm{C} / \mathrm{min}$ at first heating cycle from $-100{ }^{\circ} \mathrm{C}$ to $200{ }^{\circ} \mathrm{C}$ and followed by the cooling cycle from $200{ }^{\circ} \mathrm{C}$ to $-100{ }^{\circ} \mathrm{C}$.

\section{Physico-chemical properties of the palm oil based precursors}

\section{Results and Discussion}

Table 1 showed the physico-chemical properties of the palm oil-based precursors. The values in Table 1 were obtained using Equation (2) to (8). The acid value of POo and OA was $0.56 \%$ and increased to $8.09 \%$ and $67.32 \%$ after conversion to EPOo and diol, respectively. The iodine value of POo and OA were $61.47 \mathrm{mg} \mathrm{KOH} / \mathrm{g}$ oil and $83.91 \mathrm{mg} \mathrm{KOH} / \mathrm{g}$ oil which is almost similar to the work reported by Ramli et al. [32] at $61.67 \mathrm{mg} \mathrm{KOH} / \mathrm{g}$ oil and Derawi et al. [8, 14] at $62 \mathrm{mg} \mathrm{KOH} / \mathrm{g}$ oil, but slightly higher to the work reported by Ramli et al. [33] at $78.2 \mathrm{mg}$ $\mathrm{KOH} / \mathrm{g}$ oil for the IV value of high-oleic acid palm oil. The POo was found to have a complete epoxidization to EPOo based on the reduction of the iodine value of POo from 61.47 to $0 \mathrm{mg} \mathrm{KOH} / \mathrm{g}$ oil (Table 1), which corresponds to the complete conversion of the POo carbon double bond $(\mathrm{C}=\mathrm{C})$ to the epoxide (oxirane) ring of EPOo and similar to the reported previous study by Derawi et al. at IV 61.67 drops to 3.30 to 0.51 [14]. Due to this reason, the oxirane oxygen content (OOC) of the EPOo have increased to $3.33 \%$ compared to the POo OOC value of $0.04 \%$ only in the beginning of the reaction (Table 1). This OOC EPOo result is similar to the previous study 
reported by Giita Silverajah et al. (3.23\%) [34]. Meanwhile the saponification value of POo to EPOo was slightly reduced, 196.21 and $192.50 \mathrm{mg} \mathrm{KOH/g}$ oil, respectively. Further similarity was the slight reduction of ester value and ester percentage, which were recorded for the POo and EPOo (refer Table 1). This corresponds to the minor modification on triglyceride structure of POo by introducing epoxide ring to the POo's for producing of new triglyceride structure of EPOo [14,35].

Table 1. Physico-chemical properties of the new precursors

\begin{tabular}{lcccc}
\hline Conducted Test & $\begin{array}{c}\text { Raw Material 1: } \\
\text { Poo }\end{array}$ & $\begin{array}{c}\text { Precursor 1: } \\
\text { Epoo }\end{array}$ & $\begin{array}{c}\text { Raw Material 2: } \\
\text { OA }\end{array}$ & $\begin{array}{c}\text { Precursor 2: } \\
\text { Diol }\end{array}$ \\
\hline Acid value (\%) & 0.56 & 8.09 & 0.56 & 67.32 \\
Iodine value & 61.47 & 0 & 83.91 & - \\
(mg KOH/g oil) & & & & - \\
Oxirane oxygen content (\%) & 0.04 & 3.33 & - & 132.58 \\
Saponification value (mg KOH/g oil) & 196.21 & 192.50 & 188.80 & 114.53 \\
Hydroxyl value (mg KOH/g oil) & - & - & 231.07 & 65.26 \\
Ester value (mg KOH/g oil) & 195.65 & 184.41 & 188.24 & 14.67 \\
Ester (\%) & 43.98 & 41.45 & 42.32 & 328.30 \\
Viscosity (centipoise, cP) & 73.10 & 382.60 & 32.90 & \\
\hline
\end{tabular}

On the other hand, the saponification value of OA was decreased from $188.80 \%$ to $132.58 \%$ (Table 1) after the diol formation. This corresponds to the conversion of the carboxylic of OA to diol's ester, which was supported by the decrease in the ester value (or ester) of OA from 188.24 (or $42.32 \%$ ) to 65.26 (or 14.67\%) of diol, as well as the decrease of the hydroxyl value of OA to diol from 231.07 to 114.53 , respectively (Table 1). The dynamic viscosity of POo and OA have increased drastically in EPOo and diol form, which showed initial confirmation of the formation of the new targeted precursors of EPOo and diol (Table 1). This result will be further confirmed by the analytical measurement presented in the following sections.

The EPOo and Diol precursors' reaction mechanism

The reaction mechanism for EPOo precursor formation is essential to be identified in order to understand the in situ epoxidation of POo with peracetic acid. In this study, POo was preferable as raw material due to its valuable physicochemical properties that consist of monounsaturated triacylglycerol (TAG), POP (42.8\%), and diunsaturated TAG, POO (35.7\%), where this TAG structures can be chemically or enzymatically modified to produce new green materials for utilization in industrial and pharmaceutical products applications [8-10, 14]. Furthermore, POo is derived from natural friendly source (a liquid fraction of palm oil), it's cheaper compare to petrochemical-based products and more importantly, POo is the largest renewable resources in Malaysia [8].

Moreover, the conventional chemical treatment method is the most widely used process of epoxidation compare to such as enzymes, metal catalysts and acid ion exchange resin methods $[14,36]$. This chemical treatment method is also known as an efficient method for functionalization reactive group onto unsaturation sites (carbon double bonds) in organic compounds and resulted valuable properties of epoxides [14, 36, 37].

In this work, an established method called conventional chemical treatment by Ahmad et al. [20] is used and referred for the production of the EPOo where an alkene (POo) is reacted with peracetic acid [38-39] refer to reaction scheme (11). This epoxidation is known as an acid-catalyzed reaction [36]. The yield of reaction obtained using this method is $84.52 \%$. 


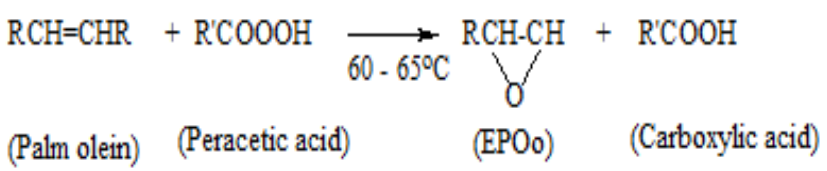

The peracetic acid solution was prepared from the glacial acetic acid ( $\mathrm{RCOOH})$ as an oxygen carrier and the hydrogen peroxide $\left(\mathrm{H}_{2} \mathrm{O}_{2}\right)$ as an oxygen donor in the presence of catalytic inorganic sulphuric acid $\left(\mathrm{H}_{2} \mathrm{SO}_{4}\right)$. The reaction mechanism of the peracetic acid formation is presented in scheme (12).

$$
\begin{array}{cccc}
\mathrm{RCOOH} & \mathrm{H}_{2} \mathrm{O}_{2} \rightleftharpoons \mathrm{R}^{\prime} \mathrm{COOOH} & +\mathrm{H}_{2} \mathrm{O} \\
\text { (Glacial acetic acid) } & \text { (Hydrogen peroxide) } & \text { (Peracetic acid) } & \text { (Water) }
\end{array}
$$

Acetic acid was found to be widely used as an oxygen carrier in the epoxidation process besides the formic acid [36]. The reaction conversion was found to be above $80 \%$ by using acetic acid, and also the higher conversion is still depends on the synthesis parameter such as temperature, reactants molar ratio, catalyst and mixing speed. In this work, the percentage of the relative conversion of the POo to EPOo, (conversion from double bonds to epoxide ring), by in situ epoxidation for 2.5 hours of reaction time is $89.04 \pm 10.56 \%$. The theoretical value of the OOC is $3.74 \%$ [14] while the value obtained in this work is 3.33\%. The OOC value was found to be different from the theoretical value probably due to the difference in the epoxidation parameters and reagent composition such as stirring speed, temperature, reaction time, type of reactants and reactants molar ratio [14, 36-37].

The catalytic inorganic of sulphuric acid have been chosen in this system because it was found to be more efficient in producing a high conversion of double bonds to epoxide ring when compared to other inorganic catalyst such as hydrochloric acid ( $\mathrm{HCI})$, nitric acid $\left(\mathrm{HNO}_{3}\right)$ and phosphoric acid $\left(\mathrm{H}_{3} \mathrm{PO}_{4}\right)$ [36, 40]. Derawi and Salimon [14] worked on the epoxidation of POo using the performic acid reaction system [14]. They found that the conversion of epoxidation is $96.5 \%$ with a reaction yield of $91.3 \%$ for 2.5 hours of reaction time. However, this epoxidation process is considered as expensive compared to using the acetic acid because formic acid is more expensive than acetic acid [14].

However the purification method that we currently used in this work would require attentive washing and transferring in the recovery of the precursors in a way to obtain higher (maximum) yield as reported by other researchers $[14,36]$.

The average MW of the POo and EPOo were 860.21 and $912.64 \mathrm{~g} / \mathrm{mol}$, respectively, which were determined by titration method utilizing saponification value (an analytical method for measuring molecular weight of triglycerides in oils) and calculated using Equation (10).

We used acid-catalyzed homogeneous esterification reaction for diol production, in the absence of solvent [15-16, $18,39]$. In this study, OA was preferable as raw material due to its valuable chemical structure that consist of a carboxyl site and a carbon-carbon double bond at the ninth position, refer to scheme (13), which is reactive and can be further modified into high value-added products [16, 40-41], as well as its a plant or bio-based oil [an 18-carbon (C18) monounsaturated fatty acid] [16,41]. This reaction system was conducted at temperature in the range of 115 $118{ }^{\circ} \mathrm{C}$, in the presence of $3 \mathrm{~A}$ molecular sieve as drying agent. The yield of reaction obtained was $72.65 \%$ for 3 hours reaction time [refer Eq. (13)]. 


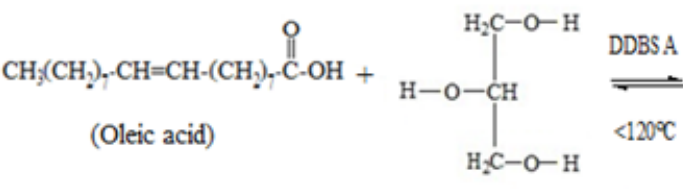

(Glycerol)

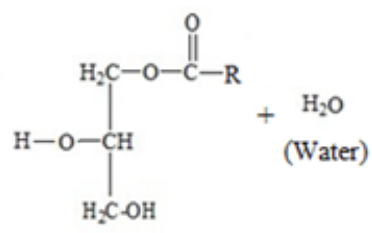

(Diol)

In this work, we used 4-dodecylbenzyl sulfonic acid (DBSA) as additive to homogenize the reaction system due to the reactants of OA and glycerol is not miscible. The DBSA was selected because it can act as emulsifier and catalyst (or known as a surfactant-type catalyst) compared to other surfactants such as cetyltrimethyl ammonium bromide (CTAB), tetradecyl trimethyl ammonium bromide (TTAB) and Esterquat [15-17]. In addition, DBSA is more efficient catalyst in water than other Bronsted acids such as $\mathrm{HCI}, \mathrm{H}_{2} \mathrm{SO}_{4}, \mathrm{H}_{3} \mathrm{PO}_{4}$ and $p$-toluenesulfonic acid (PTSA). DBSA works well for dehydration reactions such as the esterification, etherification, thioetherification, and dithioacetalization in water, hence, gaining maximum yield of reaction (approximately 96\%) [17]. This process was compared with the previous study by Kolvari et al. [17], where they conducted the condensation process of benzil ( $\mathrm{PhCOCOPh}$ ) and 1,2- diaminobenzene in $\mathrm{H}_{2} \mathrm{O}$ solvent at room temperature for 2 hours by using of $10 \%$ of the DBSA and resulted the reaction yield about a $96 \%$. The results showed that the DBSA catalyst play important role to catalyze the reactions to obtain a high yield product above a $70 \%$ for at least a 3 hours reaction time. Besides, these reaction systems is considerable as green process, non-toxic, high product yields and cheap. However, the purification method of diol need carefully washing and transferred to gain maximum yield of reaction.

The average molecular weight of diol is expected in the range of $800-1000 \mathrm{~g} / \mathrm{mol}$ [15] or less than $1500 \mathrm{~g} / \mathrm{mol}$ [18], determined by GPC. The theoretical value of the average molecular weight of oleic acid is $282.47 \mathrm{~g} / \mathrm{mol}$. Further analysis of diol for chemical structure determination using nuclear magnetic resonance (NMR) spectroscopy, gas chromatograph (GC) or gas chromatograph-mass spectrometer (GC-MS) methods will be reported in future publications to identify the possibility of nearby functional group (neighbouring group participation) involvement in the reactions, especially the carbon double bond [39].

\section{FTIR analysis for EPOo and Diol precursors}

Figure 2 showed the spectra of the POo and EPOo in transmittance mode. The presence of epoxy group absorption in the EPOo at $834 \mathrm{~cm}^{-1}$ corresponds to the formation of the epoxy ring in the EPOo molecular structure. In the previous study by few researchers [14, 19, 34, 42], the FTIR absorption of oxirane was identified at around 834 to $893 \mathrm{~cm}^{-1}$. The absorption value was found to be slightly different for each of the researchers probably due to the difference in the synthesis parameters such as reactants, catalyst, temperature and mixing speed $[14,19,34,42]$. In spite of that, the presence of the epoxy (oxirane) group in Figure 2 is strongly indicated that the EPOo was successfully synthesized via in-situ epoxidation of the POo from palm oil based.

Figure 3 showed the FTIR spectra of the OA and the diol. The O-H absorption was in the range of $3200-3600$ $\mathrm{cm}^{-1}$ corresponded to the hydroxyl group of the diol (broad). The hydroxyl value of the diol produced in this work was 114.53 (refer Table 1), which might represent at least two hydroxyl functionality in the diol, refer to scheme (13) and calculated according to Equation (9), which resulted approximately 2.78 of the hydroxyl number functionality. The average MW of the diol was taken as $1361 \mathrm{~g} / \mathrm{mol}$ [18]. Five bands for the C-O absorptions in the range of $1000-1305 \mathrm{~cm}^{-1}$ appeared in the spectra at 1010,1038,1124,1182, $1304 \mathrm{~cm}^{-1}$, which correspond to the ester functional group $[16,18]$. Furthermore the carbonyl functional group $(\mathrm{C}=\mathrm{O})$ peak at $1716 \mathrm{~cm}^{-1}$ has become shorter after the esterification due to diol formation and this has further confirmed the diol formation.

Based on the FTIR spectral analyses (refer Figure 2 and 3), the formation of EPOo and diol from POo and OA, respectively, are established. Numerous advantageous such as green renewable resources, cheaper and non-toxic were offered for utilizing a natural polymer as the raw material in designing polymeric drug vehicles [12]. Further 
analysis on the thermal properties of the precursors are required to identify and understand their degradation and thermal transition properties which are the important aspect in the design and development of polymeric drug vehicles.

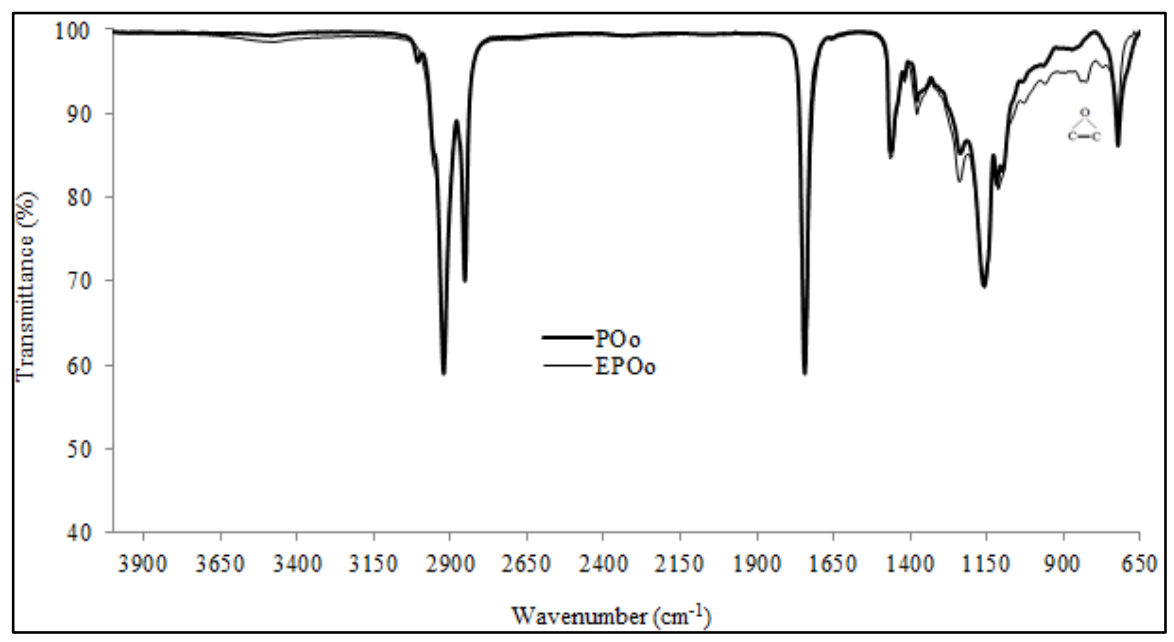

Figure 2. FTIR spectra of EPO in comparison to POo

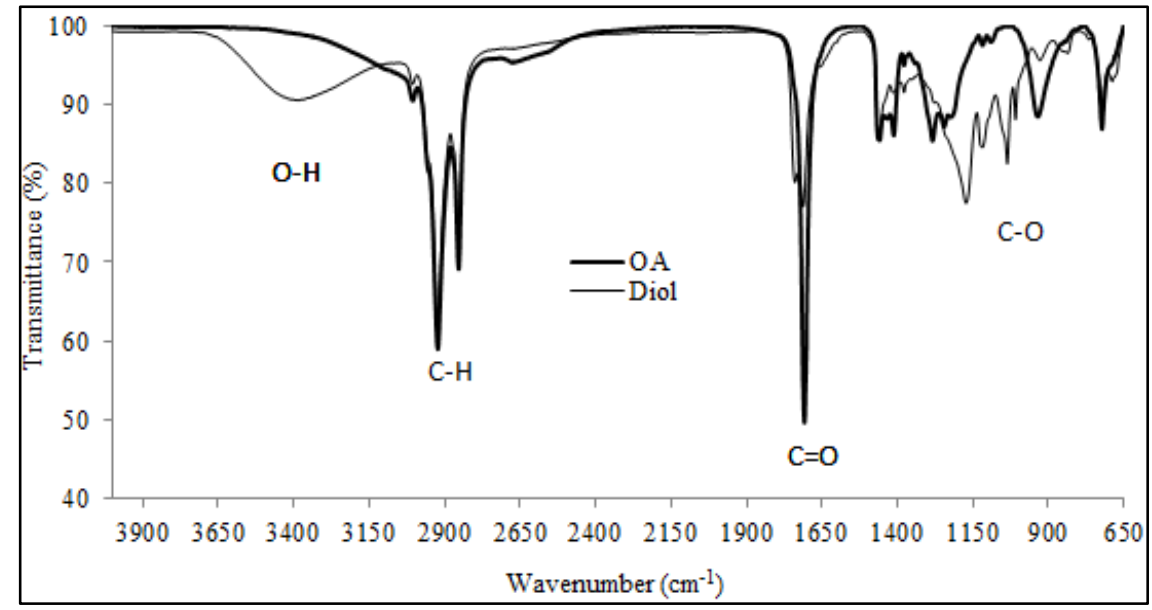

Figure 3. FTIR spectra of diol in comparison to OA

\section{Thermal analysis for EPOo and Diol precursors}

Figure 4 and 5 showed the thermal degradation (measured by TGA) and the corresponding derivative (DTG) thermograms of the POo and the EPOo, respectively. TGA thermogram curves of the POo and EPOo showed a single stage decomposition, for POo started at temperature $283{ }^{\circ} \mathrm{C}$ to $479{ }^{\circ} \mathrm{C}$ and for EPOo started at temperature $275^{\circ} \mathrm{C}$ to $523{ }^{\circ} \mathrm{C}$. Approximately about $\sim 2 \%$ weight loss at the temperature of up to $300{ }^{\circ} \mathrm{C}$ was observed, which was attributed to the loss of moisture content (Figure 5). The POo showed a degradation peak at the maximum temperature $\left(\mathrm{T}_{\max }\right)$ of $440{ }^{\circ} \mathrm{C}$ and the POo was fully degraded at higher temperature, $479{ }^{\circ} \mathrm{C}$. Meanwhile, the EPOo showed a slightly lower degradation peak at $\mathrm{T}_{\max } 407^{\circ} \mathrm{C}$ than the POo and the precursor was fully degraded at a higher temperature of $523{ }^{\circ} \mathrm{C}$, which is similar to the work reported by Tee et al. at $409{ }^{\circ} \mathrm{C}$ [43] and Giita Silverajah 
et al. at $405.1{ }^{\circ} \mathrm{C}$, respectively [34] for the peak degradation and was fully degraded at $491{ }^{\circ} \mathrm{C}$ and $504.3{ }^{\circ} \mathrm{C}$ for the EPO, respectively $[34,43]$. The presence of oxirane ring have made the EPOo to have a slightly low thermal resistance compared to POo due to the plasticization effect (soft segment) of epoxide $[34,44]$ thus having a lower degradation peak $\left(407^{\circ} \mathrm{C}\right)$ than the POo $\left(\right.$ at $\left.440{ }^{\circ} \mathrm{C}\right)$.

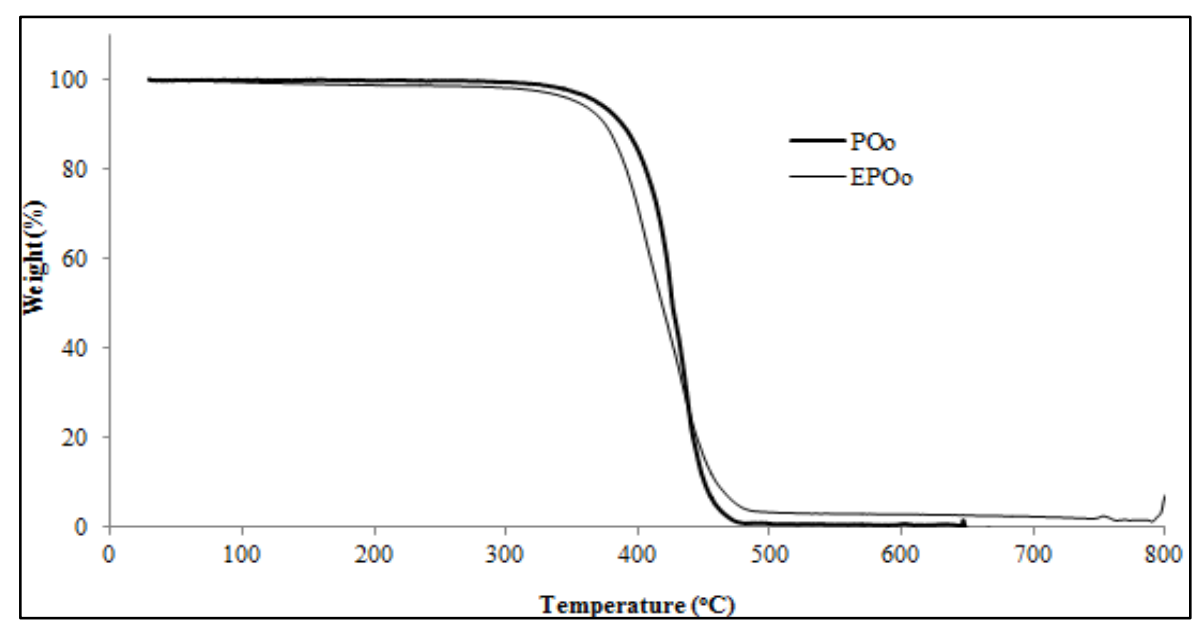

Figure 4. TGA thermograms of POo and EPOo

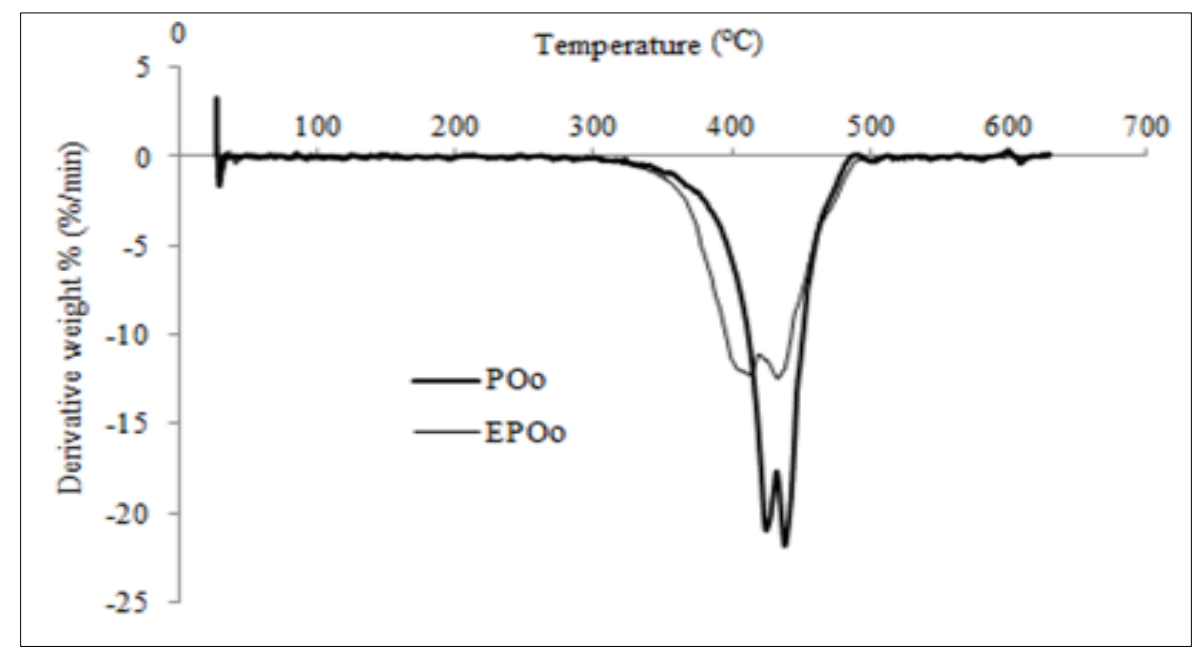

Figure 5. DTG thermograms of POo and EPOo

Figure 6 showed the DSC thermogram of the POo and the EPOo measured for the heating and cooling cycle (first heating cycle) from temperature -100 to $200{ }^{\circ} \mathrm{C}$. The DSC thermograms of POo and EPOo showed a single melting temperature $\left(\mathrm{T}_{\mathrm{m}}\right)$ peak at $5{ }^{\circ} \mathrm{C}$ and $15{ }^{\circ} \mathrm{C}$, respectively, almost in the range of the $\mathrm{T}_{\mathrm{m}}$ study reported by $[34,45-46]$. The similarity on the $\mathrm{T}_{\mathrm{m}}$ for the palm olein is at $4.74{ }^{\circ} \mathrm{C}, 6.94{ }^{\circ} \mathrm{C}, 9{ }^{\circ} \mathrm{C}$ and $17.79{ }^{\circ} \mathrm{C}$, as reported by Abdulkarim and Ghazali [45] and Zhang et al. [46], respectively. For the $\mathrm{T}_{\mathrm{m}} \mathrm{EPO}$ is shifted to $24.46{ }^{\circ} \mathrm{C}$ and $37.69{ }^{\circ} \mathrm{C}$, which is reported by Giita Silverajah [34]. 
Meanwhile three crystallization temperature $\left(\mathrm{T}_{\mathrm{c}}\right)$ of POo were observed at $\mathrm{T}_{\max }-58^{\circ} \mathrm{C}$ (in the range of -64 to $-55^{\circ} \mathrm{C}$ ), $-25{ }^{\circ} \mathrm{C}$ (in the range of -31 to $-19{ }^{\circ} \mathrm{C}$ ) and $-3{ }^{\circ} \mathrm{C}$ (in the range of -7 to $-1{ }^{\circ} \mathrm{C}$ ), of which the different finding was reported by Zhang et al. approximately at $-9.30{ }^{\circ} \mathrm{C}, 1.39{ }^{\circ} \mathrm{C}$ and $14.36{ }^{\circ} \mathrm{C}$ [46]. The EPOo thermogram also showed three $\mathrm{T}_{\mathrm{c}}$ peaks at $\mathrm{T}_{\max }-1^{\circ} \mathrm{C}$ (in the range of -4 to $2{ }^{\circ} \mathrm{C}$ ), $5{ }^{\circ} \mathrm{C}$ (between $2-8{ }^{\circ} \mathrm{C}$ ) and $26{ }^{\circ} \mathrm{C}$ (in the range of 20 to $29^{\circ} \mathrm{C}$ ) when the sample is being cooled (Figure 6). This result is similar to the study reported by Tan and Chow where one of the EPO $T_{c}$ is at $-0.97^{\circ} \mathrm{C}$, which is in the range of temperatures between $T_{g}$ and $T_{m}$ when the sample is being cooled [47].

The glass transition temperature $\left(\mathrm{T}_{\mathrm{g}}\right)$ of EPOo was found approximately at $\mathrm{T}_{\max }-7^{\circ} \mathrm{C}$, occurred in the range of -16 to $2{ }^{\circ} \mathrm{C}$ (Figure 6). The $\mathrm{T}_{\mathrm{g}}$ of EPOo was found to be different from the finding reported by Tan and Chow at $-18^{\circ} \mathrm{C}$ [47] due to the difference composition of the palm oil been used such as from the palm oil by Tan and Chow and from the palm olein in our study. The $\mathrm{T}_{\underline{g}}$ of the POo could not be observed in the DSC thermogram (Figure 6), which is might due to the weak transition of $\mathrm{T}_{\mathrm{g}}$ especially for crystalline and low amorphous materials [47].

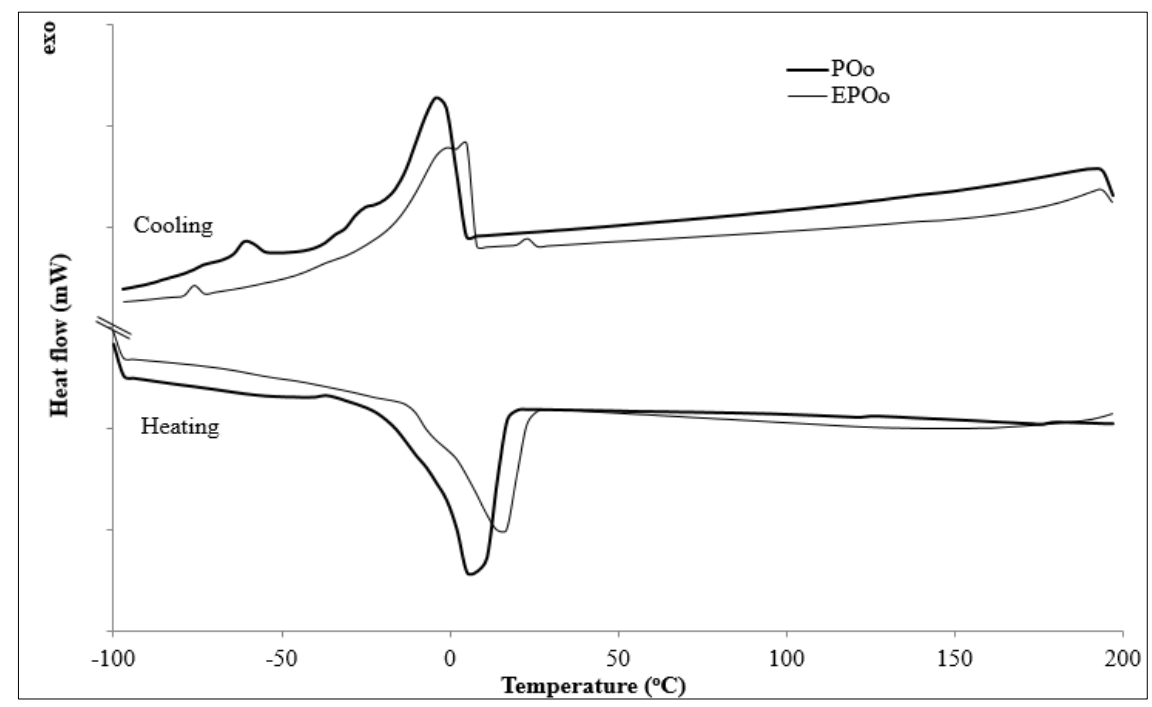

Figure 6. DSC thermograms of POo and EPOo

The TGA and DTG thermograms of the oleic acid and the diol are presented in the respective Figure 7 and 8 . The thermogram patterns of both showed low thermal resistance of diol where the decomposition for OA started at temperature $180^{\circ} \mathrm{C}$ to $438{ }^{\circ} \mathrm{C}$. Meanwhile, the decomposition of diol started at temperature $108{ }^{\circ} \mathrm{C}$ to $516{ }^{\circ} \mathrm{C}$. TGA curves of oleic acid and diol (Figure 7) showed two and three stages decomposition, respectively. In the oleic acid thermogram, the first stage represented the major degradation of the $\mathrm{OA}$ at $\mathrm{T}_{\max } 291{ }^{\circ} \mathrm{C}$ (in the range of 124 to $323^{\circ} \mathrm{C}$ ). This might be attributed to the loss of fatty acid in oleic acid, a carboxylic acid, which is about $\sim 88 \%$ from the total weight loss. The second stage occurred at $\mathrm{T}_{\max } 347^{\circ} \mathrm{C}$ (in the range of 325 to $411^{\circ} \mathrm{C}$ ), which probably due to the total weight loss of carbon double bonds $(\mathrm{C}=\mathrm{C})$ and hydrocarbon $(\mathrm{C}-\mathrm{H})$ of about $\sim 8 \%$. The $\mathrm{OA}$ was found to completely degrade at $438^{\circ} \mathrm{C}$.

Meanwhile the first stage degradation in the diol thermogram showed a slower decomposition process (than the OA) which is about $\sim 14 \%$ of the total weight loss at $\mathrm{T}_{\max } 125{ }^{\circ} \mathrm{C}$ (in the range of 79 to $200{ }^{\circ} \mathrm{C}$ ). This might be attributed to the decomposition of hydroxyl group $(\mathrm{O}-\mathrm{H})$, which was produced from the hydroperoxide group (-OOH) (formed from oxidation of oil) and was found to be unstable at above $100{ }^{\circ} \mathrm{C}$ [48]. The decomposition of the hydroperoxide involved cleavage of the $\mathrm{O}-\mathrm{O}$ bond in the hydroperoxide hence produced hydroxy-radical [48]. Based on this justification, the first stage decomposition temperature in the diol was strongly attributed to degradation of hydroxyl group. 
In the second stage degradation, the major degradation of diol was recorded at $\mathrm{T}_{\max } 362{ }^{\circ} \mathrm{C}$ (in the range of 204 to $426{ }^{\circ} \mathrm{C}$ ), which consist of about $\sim 76 \%$ of the major total weight loss. This involved bond cleavage on the carboxyl site which later produced ester group in the formation of ester radical. Thus, it can be concluded that this second stage decomposition pattern was possibly attributed to the degradation of the ester group (C-O) (Figure 7 and 8). The third stage degradation is about $\sim 4$ weight loss at $\mathrm{T}_{\max } 492{ }^{\circ} \mathrm{C}$ (in the range of 457 to $516{ }^{\circ} \mathrm{C}$ ), which might be attributed to bond cleavage of carbon double bond $(\mathrm{C}=\mathrm{C})$ and hydrocarbon $(\mathrm{C}-\mathrm{H})$ sides and further heating at 516 ${ }^{\circ} \mathrm{C}$ showed a complete degradation of diol.

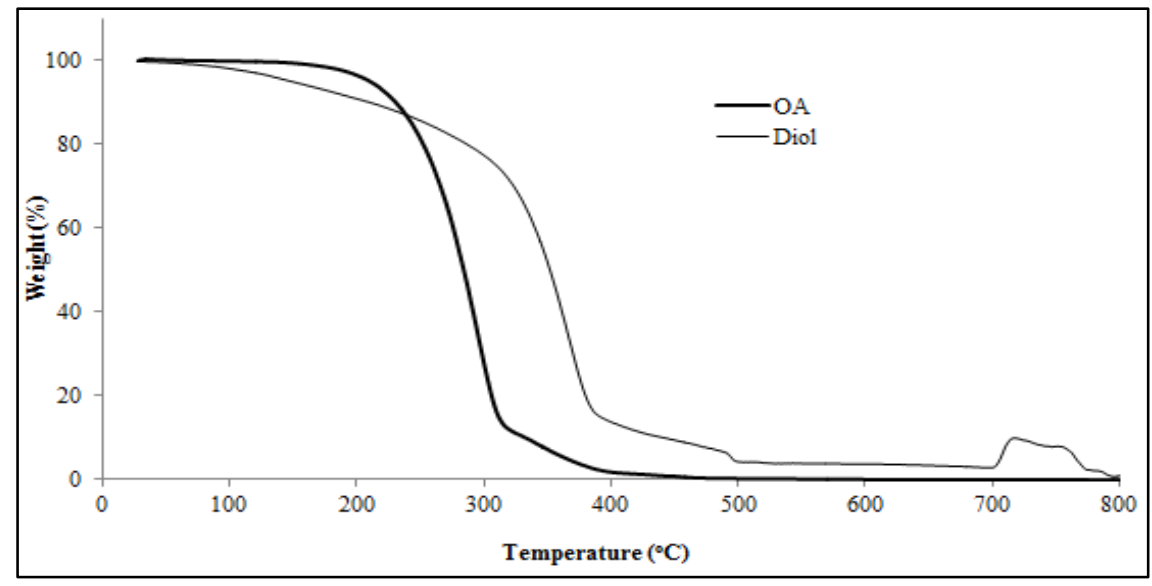

Figure 7. TGA thermograms of $\mathrm{OA}$ and diol

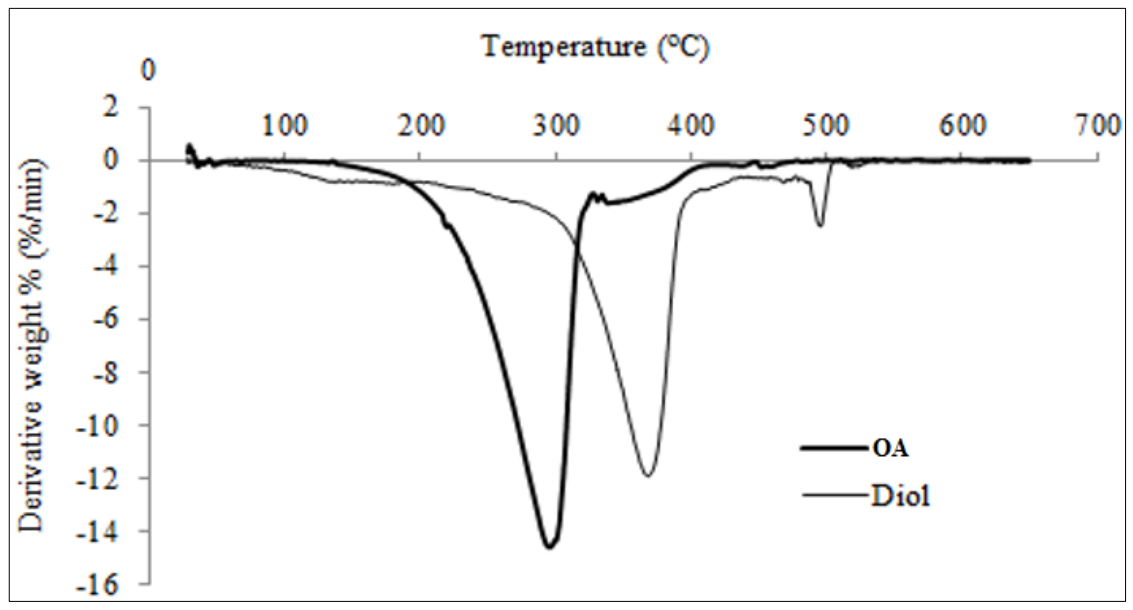

Figure 8. DTG thermograms of OA and diol

Figure 9 shows the DSC thermograms of the oleic acid and the diol. Two melting peaks of oleic acid were indicated at $\mathrm{T}_{\max }-25^{\circ} \mathrm{C}$ (in the range of -31 to $-13{ }^{\circ} \mathrm{C}$ ) and $10{ }^{\circ} \mathrm{C}$ (in the range of $2{ }^{\circ} \mathrm{C}$ to $23{ }^{\circ} \mathrm{C}$ ) and also two $\mathrm{T}_{\mathrm{c}}$ peaks of oleic acid were occurred at $\mathrm{T}_{\max }-27^{\circ} \mathrm{C}$ (in the range of -31 to $-22{ }^{\circ} \mathrm{C}$ ) and $-5^{\circ} \mathrm{C}$ (in the range of -10 to $-1{ }^{\circ} \mathrm{C}$ ) (Figure 9). The oxidative of oleic acid was associated with the thermal decomposition (Figure 7 and Figure 8) which was started from $124{ }^{\circ} \mathrm{C}$ to $\mathrm{T}_{\max }$ at $151{ }^{\circ} \mathrm{C}$ (in the range of 124 to $173{ }^{\circ} \mathrm{C}$ ), as shown in Figure 9 . 
Four peaks of the diol $\mathrm{T}_{\mathrm{m}}$ occurred at $\mathrm{T}_{\max }-40{ }^{\circ} \mathrm{C},-27^{\circ} \mathrm{C},-4{ }^{\circ} \mathrm{C}$ (in the range of -49 to $5{ }^{\circ} \mathrm{C}$ ) and $133{ }^{\circ} \mathrm{C}$ (in the range of 112 to $142{ }^{\circ} \mathrm{C}$ ), as shown in Figure 9. The diol thermogram also showed one $\mathrm{T}_{\mathrm{c}}$ peak occurred at $\mathrm{T}_{\max }-21.81{ }^{\circ} \mathrm{C}$ (in the range of -36 to $-13{ }^{\circ} \mathrm{C}$ ). The $\mathrm{T}_{\mathrm{g}}$ oleic acid is detectable at $2.18{ }^{\circ} \mathrm{C}$ (in the range of $-0.67{ }^{\circ} \mathrm{C}$ to $5.18{ }^{\circ} \mathrm{C}$ ), as shown in the DSC thermogram. The $\mathrm{T}_{\mathrm{g}}$ of the diol was observed at $\mathrm{T}_{\max }-57^{\circ} \mathrm{C}$ and $-12.59{ }^{\circ} \mathrm{C}$ (Figure 9), which showed that the diol contains soft and hard segment of molecules structure where the $\mathrm{T}_{\mathrm{g}}$ peaks occurred in the range of $T_{m}$ and $T_{c}$ temperatures [16, 41]. Besides, the diol $T_{g}$ results is near to the range of the study reported by Mohd Mustafa et al. at $-33.87^{\circ} \mathrm{C},-18.29^{\circ} \mathrm{C}$ and $-15.28^{\circ} \mathrm{C}$ [49]. The study reported the palm oleic acid based alkyd resins were prepared from oleic acid and glycerol with the presence of phthalic anhydride using the one step fatty acid process technique for two hours [49]. The similarity between these studies is the process systems are conducted in the absence of solvent.

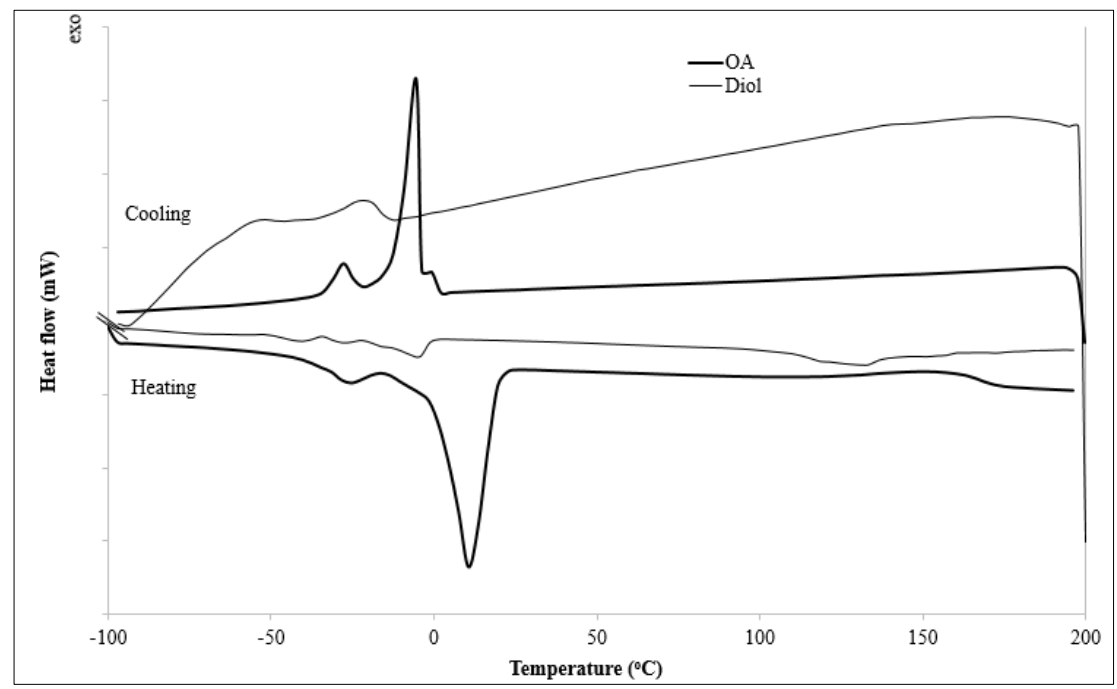

Figure 9. DSC thermograms of OA and diol

The thermal properties of the precursors in comparison to their raw materials found in this study (measured from the TGA, DTG and DSC analyses) are consistent and in line with the chemical properties obtained from the FTIR spectral analysis in Figure 2 and 3, such as the appearance of the functional groups of epoxy (oxirane) in the EPOo and hydroxyl and ester in the diol. This thermal property provided the overview of the degradation mechanisms and thermal transition $\left(\mathrm{T}_{\mathrm{g}}, \mathrm{T}_{\mathrm{c}}\right.$ and $\left.\mathrm{T}_{\mathrm{m}}\right)$ of EPOo and diol. The thermal properties will be useful in elucidating the degradation and thermal behavior in designing and developing the future polymeric drug delivery vehicles.

\section{Conclusion}

The synthesis of palm oil-based precursors namely EPOo and diol via in-situ epoxidation and esterification techniques using the respective POo and OA were successfully conducted. The procedures offer several advantages including cheap, cleaner reactions and high yields as confirmed by the proposed mechanism. The precursors exhibited promising physicochemical and thermal properties that could be used in designing new polymers such as acrylated palm oil (APOo) and polyol polyester for application in drug delivery system. These new precursors can be further investigated to be used in designing new concepts of biomaterial to create smart polymeric drug vehicle due to their soft, flexible and thermal resistance properties as confirmed by the FTIR, TGA, DTG and DSC analyses.

\section{Acknowledgement}

The authors gratefully acknowledge Malaysia Nuclear Agency for materials and instruments support (NM-R\&D-1501), the Division of Radiation Processing Technology, the Radiation Curing and Synthesis Group and Universiti Kebangsaan Malaysia for providing the research grant of GUP/086/2016. 


\section{References}

1. Liechty, W. B., Kryscio, D. R., Slaughter, B. V. and Peppas, N. A. (2010). Polymers for drug delivery systems. Annual Review Chemical and Biomolecular Engineering, 1: 149 - 173.

2. Vilara, G., Tulla-Puche, J. and Albericio, F. (2012). Polymers and drug delivery systems. Current Drug Delivery, 9(4): 1 - 24.

3. Saurabh, K. V., Rani, S., Rani, S. and Kesari, A. (2013). Drug targeting by erythrocytes: A carrier system. Scholars Academic Journal of Pharmacy, 2(2): 144 - 156.

4. Srikanth, K., Rama Mohan Gupta, V., Manvi, S. R. and Devanna, N. (2012). Particulate carrier systems - a review. International Research Journal of Pharmacy, 3(11): 22 - 26.

5. Takakura, Y. and Hashida, M. (1996). Macromolecular carrier systems for targeted drug delivery: Pharmacokinetic considerations on biodistribution. Pharmaceutical Research, 13(6): 820 - 831.

6. Abdelwahab, S. I., Sheikh, B. Y., Elhassan Taha, M. M., Chee, W. H., Abdullah, R., Yagoub, U., El-Sunousi, R. and Eid, E. E. (2013). Thymoquinone-loaded nanostructured lipid carriers: preparation, gastroprotection, in vitro toxicity, and pharmacokinetic properties after extravascular administration. International Journal of Nanomedicine, 8: 2163 - 2172.

7. Baharu, M. N., Kadhum, A. A. H., Al-Amiery, A. A., and Mohamad, A. B. (2015). Synthesis and characterization of polyesters derived from glycerol, azelaic acid, and succinic acid. Green Chemistry Letters and Reviews, 8(1): 31 - 38.

8. Derawi, D., Abdullah, B. M., Huri, H. Z., Yusop, R. M., Salimon, J., Hairunisa, N. and Salih, N. (2014). Palm olein as renewable raw materials for industrial and pharmaceutical products applications: chemical characterization and physicochemical properties studies. Advances in Materials Science and Engineering, 2014:1 - 5.

9. Tajau, R., Mohd Dahlan, K. Z., Mahmood, M. H., Wan Yunus, W. M. Z., Ismail, M., Salleh, M. and Muhammad Faisal, S. (2012). Acrylated vegetable oil nanoparticle as a carrier and controlled release of the anticancer drug-thymoquinone. International Conference on Enabling Science and Nanotechnology 2012 (ESciNano 2012), Persada Johor International Convention Center, Johor Bahru, Malaysia.

10. Tajau, R., Wan Yunus, W. M. Z., Mohd Dahlan, K. Z., Mahmood, M. H., Hashim, K., Ismail, M., Salleh, M. Z. and Che Ismail, R. (2013b). Radiation-induced formation of acrylated palm oil nanoparticle using pluronic f127 microemulsion system. Pertanika Journal of Science and Technology, 21 (21): 135 - 142.

11. Zainol, S., Basri, M., Basri, H., Shamsuddin, A. F., Abdul-Gani, S. S., Abedi Karjiban, R. and Abdul-Malek, E. (2012). Formulation Optimization of a palm-based nanoemulsion system containing levodopa. International Journal of Molecular Sciences, 13: 13049 - 13064.

12. Vroman, I. and Tighzert, L. (2009). Biodegradable polymers. Materials, 2: 307 - 344.

13. Goud, V. V., Dinda, S., Patwardhan, A. V. and Pradhan, N. C. (2010). Epoxidation of Jatropha (Jatropha curcas) oil by peroxyacids. Asian-Pacific Journal of Chemical Engineering, 5: 346 - 354.

14. Derawi, D. and Salimon, J. (2010). Optimization on epoxidation of palm olein by using performic acid. $E$ Journal of Chemistry, 7(4): 1440 - 1448.

15. Mahmood, M. H., Tajau, R., Salleh, M. Z. and Che Ismail, R. (2011). Malaysia Patent No. MY-142814-A: Method for manufacturing palm oil based hydroxyl containing products for use in making polyurethane materials.

16. Rihayat, T. and Suryani. (2010). Synthesis and properties of biobased polyurethane/montmorillonite nanocomposites. World Academy of Science, Engineering and Technology, 4(5): 714 - 718.

17. Kolvari, E., Zolfigol, M. A. and Peiravi, M. (2012). Green synthesis of quinoxaline derivatives using pdodecylbenzensulfonic acid as a surfactant-type Bronsted acid catalyst in water. Green Chemistry Letters and Reviews, 5(2): 155 - 159.

18. Tajau, R., Mahmood, M. H., Salleh, M. Z., Che Ismail, R., Abang Othman, A. M., Abdul Rahman, F. and Mohd Dahlan, K. Z. (2008). Synthesis and characterization of a highly-functional polyol-polyurethane based palm oil for photo-curable resin. The Nuclear Malaysia R\&D Seminar 2008, Selangor, Malaysia.

19. Tajau, R., Mahmood, M. H., Salleh, M. Z., Mohd Dahlan, K. Z., Che Ismail, R., Muhammad Faisal, S. and Sheikh Abdul Rahman, S. M. Z. (2013a). Production of uv-curable palm oil resins/oligomers using laboratory scale and pilot scale systems. Sains Malaysiana, 42(44): 459 - 467. 
20. Ahmad, S., Rafie, A. and Ismail, Z. (1987). PORIM Report PO (125a) 87: Epoxidized palm oil and palm stearin as plasticizer/stabilizer. Selangor, Malaysia: Palm Oil Research Institute of Malaysia (PORIM).

21. Bolley, D. S., Gall, R. J., Goldsmith, W. F., Maerker, G., Pohle, W. D., Sobatzki, R. J., Walker, R.O. and Barlow, D. O. (1964). Report of the epoxidized oils subcommittee on oxirane oxygen. Journal of the American Oil Chemists Society, 41(1): 86 - 87.

22. ASTM. (2011). D974: Standard test method for acid and base number by color-indicator titration. West Conshohocken, Pennsylvania, Unites State of America: ASTM International.

23. ASTM. (1979). D 1962-67: Test for saponification value of drying oils, fats and polymerized fatty acids. Annual Book of American Society for Testing and Material (ASTM) Standards. 29: 259 - 261.

24. AOCS. (1988). Cd 1-25: Iodine Value of Fats and Oils Wijs Method. The American Oil Chemists' Society (AOCS) Official Method.

25. Beare-Rogers, J., Dieffenbacher, A., and Holm, J. V. (2001). International Union of Pure And Applied Chemistry (IUPAC) joint committee of International Union of Nutritional Sciences and Iupac Commission on Food: Lexicon of lipid nutrition. Pure Applied Chemistry, 73(4): 685 - 744.

26. Codex, F. C. (1972). Food Chemicals Codex Second Edition. United State of America: National Academic of Sciences, Washington.

27. Lubrizol. (2015). Lubrizol test procedure. TP-TM-006C: Determination of saponification value: pp. 1 - 2.

28. ASTM. (2000). D 4274 - 99: Standard test methods for testing polyurethane raw materials: Determination of hydroxyl numbers of polyols. Annual Book of ASTM Standards.

29. Ionescu, M. (2005). Chemistry and technology of polyols for polyurethanes. Rapra Technology Limited. Shropshire, United Kingdom.

30. Brookfield. (2015). Operating instructions (Manual No. M/03-165-C0508W) for Brookfield Digital Viscometer Model DV-II. Brookfield Engineering Laboratories Inc. Stoughton, Massachusetts, U.S.A.

31. $\mathrm{Xu}, \mathrm{H}$., Miao, X. and $\mathrm{Wu}, \mathrm{Q}$. (2006). High quality biodiesel production from a microalga Chlorella protothecoides by heterotropic growth in fermenters. Journal of Biotechnology, 126: 499 - 507.

32. Ramli, M. R., Siew, W. L. and Cheah, K. Y. (2009). Production of high oleic palm oils on a pilot scale. Journal of the American Oil Chemists' Society, 86(8): 587 - 594.

33. Ramli, M. R., Siew, W. L. and Cheah, K. Y. (2008). Properties of high-oleic palm oils derived by fractional crystallization. Journal of Food Science, 73(3): 140 - 145.

34. Giita Silverajah, V. S., Ibrahim, N. A., Zainuddin, N., Wan Yunus, W. M. Z., and Abu Hassan, H. (2012). Mechanical, thermal and morphological properties of poly(lactic acid)/epoxidized palm olein blend. Molecules, 17: 11729 - 11747.

35. Derawi, D. and Salimon, J. (2013). Palm olein polyols production by batch and continuous hydrolysis. Sains Malaysiana, 42(8): 1121 - 1129.

36. Saurabh, T., Patnaik, M., Bhagt, S. L. and Renge, V. C. (2011). Epoxidation of vegetable oils: A review. International Journal of Advanced Engineering Technology, 2(4): 491 - 501.

37. Saurabh, T., Patnaik, M., Bhagat, S. L. and Renge, V. C. (2012). Studies on synthesis of biobased epoxide using cottonseed oil. International Journal of Advanced Engineering Research and Studies, 1(2): 279 - 284.

38. Bartlett, P. D. (1950). Recent work on the mechanisms of peroxide reactions. Record of Chemical Progress, 11: $47-51$.

39. Scrimgeour, C. (2005). Chemistry of fatty acids. $6^{\text {th }}$ Edition. John Wiley \& Sons. Inc., Publishers, Scotlands.

40. Salimon, J., Abdullah, B., M., Yusop, R. M. and Salih, N. (2014). Synthesis, reactivity and application studies for different biolubricants. Chemistry Central Journal, 8(1): 1 -11.

41. Lligadas, G., Ronda, J. C. and Cádiz, M. G. V. (2010). Oleic and undecylenic acids as renewable feedstocks in the synthesis of polyols and polyurethanes. Polymers, 2: 440 - 453.

42. Czub, P. and Franek, I. (2013). Epoxy resins modified with palm oil derivatives - preparation and properties. Polimery, 58(2): 135 - 139.

43. Tee, Y. B., Talib, R. A., Abdan, K., Chin, N. L., Basha, R. K. and Md Yunos, K. F. (2016). Comparative study of chemical, mechanical, thermal and barrier properties of poly(lactic acid) plasticized with epoxidized soybean oil and epoxidized palm oil. BioResource, 11(1): 1518 - 1540.

44. Giita Silverajah, V. S., Ibrahim, N. A., Wan Yunus, W. M. Z., Abu Hassan, H. and Chieng, B. W. (2012). A comparative study on the mechanical, thermal and morphological characterization of poly(lactic acid)/epoxidized palm oil blend. International Journal of Molecular Sciences, 13: 5878 -5898. 
45. Abdulkarim, S. M., and Ghazali, H. M. (2007). Comparison of melting behaviors of edible oils using conventional and hyper differential scanning calorimetric scan rates. ASEAN Food Journal, 14(1): 25 -35.

46. Zhang, X., Li, L., Xie, H., Liang, Z., Su, J., Liu, G. and Li, B. (2013). Comparative analysis of thermal behavior, isothermal crystallization kinetics and polymorphism of palm oil fractions. Molecules, 18: 1036 1052 .

47. Tan, S. G. and Chow, W. S. (2010). Thermal properties of anhydride-cured bio-based epoxy blends. Journal of Thermal Analysis and Calorimetry, 101: $1051-1058$.

48. Mahungu, S. M., Hansen, S. L. and Artz, W. E. (1998). Volatile compounds in heated oleic acid-esterified propoxylated glycerol. Journal of the American Oil Chemists' Society, 75(6): 683 - 690.

49. Mohd Mustafa, S. F., Gan, S. N. and Yahya, R. (2013). Synthesis and characterization of novel alkyds derived from palm oil based polyester resin. Asian Journal of Chemistry, 25(15): 8737 - 8740. 